\title{
Surface Roughness of a Dental Ceramic After Polishing with Different Vehicles and Diamond Pastes
}

\author{
Guilherme Brião CAMACHO ${ }^{1}$ \\ Dionísio VINHA ${ }^{2}$ \\ Heitor PANZERI ${ }^{3}$ \\ Tomio NONAKA ${ }^{2}$ \\ Mariane GONÇALVES ${ }^{3}$ \\ ${ }^{1}$ Department of Dental Materials and Prosthodontics, \\ School of Dentistry, Federal University of Pelotas, Pelotas, RS, Brazil \\ ${ }^{2}$ Department of Restorative Dentistry, \\ School of Dentistry of Ribeirão Preto, University of São Paulo, Ribeirão Preto, SP, Brazil \\ ${ }^{3}$ Department of Dental Materials and Prosthodontics, \\ School of Dentistry of Ribeirão Preto, University of São Paulo, Ribeirão Preto, SP, Brazil
}

\begin{abstract}
During fabrication of bonded ceramic restorations, cervical adaptation, occlusal adjustment and final finishing/polishing are procedures to be performed at the dental office after adhesive cementation. Final adjustments may result in loss of ceramic glaze, which requires new polishing of the ceramic surface, with special attention for selection of adequate materials and instruments. The purpose of this study was to evaluate the efficiency of different vehicles associated with diamond pastes indicated for dental ceramic polishing. Two polishing pastes (Crystar Paste and Diamond Excell) associated with four vehicles (rubber cup, Robinson bristle brush, felt wheel and buff disc) were evaluated. Disc-shaped specimens were fabricated from Ceramco II dental ceramic. Surface roughness means ( $R a$ ) of the ceramic specimens were determined with a rugosimeter. Data were analyzed statistically by two-way ANOVA and Tukey's test at $5 \%$ significance level. There was no statistically significant difference $(p>0.01)$ between the polishing pastes. However, there were statistically significant differences $(\mathrm{p}<0.01)$ among the tested vehicles. Vehicle-paste interaction showed statistically significant difference $(p<0.05)$ as well. It may be concluded that: 1$)$ Robinson bristle brush, felt wheel and buff disc were efficient vehicles to be used in association with a diamond polishing paste; 2) The use of rubber cup as a vehicle showed poor efficiency for mechanical polishing of the ceramic surfaces; 3) Both pastes provided similar and efficient polishing and may be recommended for use with an appropriated vehicle.
\end{abstract}

Key Words: surface roughness, dental ceramic, polishing, diamond paste, vehicle.

\section{INTRODUCTION}

Esthetic restorative dentistry has undergone a great development in the last years. There is a consensus that among the available esthetic materials, dental ceramic has the best characteristics of durability, wear resistance and esthetics. Ceramic restorations are esthetically very close to the dental structure and maintain this characteristic for a long time.
The development of new techniques and ceramic systems for esthetic restorations, such as the inlays, onlays and porcelain veneers, widely employed at present (1-3) and with seemingly good esthetic, functional properties and good wear resistance $(1,4,5)$, point out a serious problem: which is the most satisfactory surface treatment to be performed when these restorations present some kind of wear and cracking?

The ceramic surface is traditionally subjected to

Correspondence: Profa. Dra. Mariane Gonçalves, Faculdade de Odontologia de Ribeirão Preto, Universidade de São Paulo, Departamento de Materiais Dentários e Prótese, Avenida do Café, s/n, 14040-904 Ribeirão Preto, SP, Brasil. Tel: +55-16-3602-4334. Fax: +55-163633-0999. e-mail: ane.gon@netsite.com.br 
a superficial treatment known as "glazing” or simply "glaze". A surface finishing is performed with abrasive tips followed by a heat treatment that melts the superficial layer, resulting in a proper surface smoothness (6). In contrast, mechanical polishing may produce different characteristics. Polishing of porcelains is performed after adjusting occlusion either in the laboratory or at the dental office $(7,8)$.

It is important to highlight that some kind of finishing and polishing should be performed after fabrication of the restoration. This step is particularly time-consuming in adhesive ceramic restorations because occlusal checking and adjustment of such types of prosthesis can only be performed after cementation (8). This procedure, however, removes the ideal glazing, requiring a new polishing of the surface during the clinical session $(9,10)$. Polishing improves structural resistance $(11,12)$ to withstand oral conditions $(11,13)$, and ensures optical characteristics.

Little information is currently available about the vehicles for application of abrasive finishing pastes. Therefore, the purpose of this study was to evaluate the efficiency of different vehicles associated with different diamond polishing pastes indicated for dental ceramic polishing.

\section{MATERIAL AND METHODS}

Disc-shaped ceramic specimens (3-mm-thick; 7-mm-diameter) were fabricated from a feldspathic ceramic (Ceramco II; Ceramco Inc., Burlington, NJ, USA). Crystar Paste (Kota Ind. e Com. Ltda., São Paulo, SP, Brazil) and Diamond Excel (FGM Produtos Odontológicos, Joinville, SC, Brazil) diamond pastes were used for ceramic polishing. Four different vehicles were used for application of the polishing pastes: dental rubber cup (Webbed Latch; DentAmerica Ind., Bedford Circle, CA, USA), Robinson bristle brush (One Gross; DentAmerica Ind.), felt wheel (Mini Felt Wheel; Kota Ind. e Com. Ltda.) and buff discs (SuperSnap Buff Discs; Shofu Inc., Kyoto, Japan). The experimental groups were compared to a control group consisting of non-polished abraded ceramic surfaces.

The ceramic specimens were fabricated using a circular stainless steel matrix following a two-step technique (baking at $918^{\circ} \mathrm{C}$ and autoglazing at $920^{\circ} \mathrm{C}$ ). After fabrication, the specimens were ground with water-cooled sandpapers of decreasing abrasiveness
(\#280-, \#400- and \#600-grit) to flatten the ceramic surfaces and standardize roughness. A total of 63 specimens were fabricated and randomly assigned to 9 groups (8 experimental and 1 control). The same operator performed all laboratory procedures in order to standardize manual pressure, speed (low-speed handpiece) and number of repetitions for application of the vehicles and pastes during the polishing procedures. The same technical sequence was followed for all experiments. The polishing paste was spread on the ceramic surface and then the operator performed a cycle of 30 eight-shaped movements with each vehicle under a constant light manual pressure. During polishing, the specimens were cooled with a continuous air-jet blowing. The polished specimens were thoroughly washed and dried for subsequent surface roughness assessment

Roughness $(R a)$ was measured using a digital roughness meter (RUG-03 Prazis, ARO SA, Buenos Aires, Argentine) accurate to $1.5 \mathrm{~mm}$ Lt. Roughness measurements were performed in compliance with the specifications of ISO 4287 standard (Geometrical product specification (GPS). Surface texture. Profile method. Terms, definitions and surface texture parameters). Five measurements were made on the center of each specimen in different directions and the average was calculated.

Data were analyzed statistically by two-way ANOVA and Tukey's test at 5\% significance level.

\section{RESULTS}

Surface roughness means $(R a$; in $\mu \mathrm{m})$ obtained with the tested vehicles using either of the diamond polishing pastes are given on Table 1 .

The ANOVA test demonstrated no statistically significant difference ( $>0.01$ ) between the polishing

Table 1. Surface roughness means ( $R a$; in $\mu \mathrm{m}$ ) obtained with the tested vehicles using either of the diamond polishing pastes.

\begin{tabular}{lcccc}
\hline & $\begin{array}{c}\text { Rubber } \\
\text { cup }\end{array}$ & $\begin{array}{c}\text { Robinson } \\
\text { brush }\end{array}$ & $\begin{array}{c}\text { Felt } \\
\text { wheel }\end{array}$ & $\begin{array}{c}\text { Buff } \\
\text { disc }\end{array}$ \\
\hline Crystar Paste & 0.255 & 0.098 & 0.107 & 0.119 \\
Diamond Excell & 0.242 & 0.088 & 0.119 & 0.087 \\
\hline
\end{tabular}

$R a$ in the non-polished control group was $0.349 \mu \mathrm{m}$. 
pastes. Nevertheless, there were statistically significant differences $(p<0.01)$ among the vehicles evaluated in this study. Among the experimental groups, the use of rubber cup provided statistically significant higher $(p<0.01)$ surface roughness on the ceramic specimens than the other vehicles. Robinson bristle brush, felt wheel and buff disc presented statistically similar results to each other ( $p>0.01)$. The non-polished control specimens showed significantly higher $(p<0.01)$ surface roughness than the polished specimens, regardless of the vehicle used (Table 2).

\section{DISCUSSION}

As far as it could be ascertained, there are no published studies addressing the efficiency of polishing paste vehicles in maintaining the original physical properties and longevity of ceramic restorations. The reason for this is that most authors have investigated the clinical performance of ceramic restorations (14-17). Therefore, the data obtained in the present study cannot be compared to those of previous works.

In the present study, it was observed that Robinson bristle brush provided lower roughness means than felt wheel and buff disc (SuperSnap) but this difference was not statistically significant. This result indicates that these three vehicles had similar efficiency for mechanical polishing of ceramic surfaces when associated with a diamond paste.

On the other hand, polishing with a rubber cup as a vehicle resulted in significantly higher roughness (and thus lower efficiency) than that observed for the other tested vehicles. This outcome suggests that the use of rubber cups for polishing ceramic restorations is not advisable. The poor efficiency of the rubber cups as

Table 2. Results of Tukey's test for the variable vehicle.

\begin{tabular}{lc}
\hline Vehicles & Surface roughness means $(R a ;$ in $\mu \mathrm{m})$ \\
\hline Control group & $0.34971 \mathrm{a}$ \\
Rubber cup & $0.24864 \mathrm{~b}$ \\
Felt wheel & $0.11314 \mathrm{c}$ \\
Buff disc & $0.10357 \mathrm{c}$ \\
Robinson brush & $0.09364 \mathrm{c}$ \\
\hline
\end{tabular}

Different letters indicate statistically significant difference at $\mathrm{p}<0.01$ (Tukey’s critical value $=0.02576$ ). polishing paste vehicles might be explained by the limited retention of the paste on its surface during the procedure. Furthermore, an increase of temperature was observed on the ceramic surface when the rubber cups were employed. This temperature rise was easily perceived by touch and was higher than that recorded for the other vehicles. This is due to thermal difference generated on the ceramic, which can cause microfissures on the ceramic surface (9). Fissures can decrease the ceramic structural strength and contribute to the failures.

The polishing pastes evaluated in this study had a similar behavior. Crystar Paste and Diamond Excell diamond pastes were efficient in decreasing the irregularities on ceramic specimens. A previous study (18) found that that the size and cross-section of the abrasive particles influence the abrasive potential of the diamond pastes. Therefore, the results of this study indicate that these pastes have similar physical characteristics regarding the type, size and distribution of diamond particles (18). However, it can only be confirmed by a structural analysis of the composition of these pastes.

The vehicle-paste interactions showed statistical significance and it was observed that the vehicles behaved differently for each tested paste. If one of the pastes had better performance with a certain vehicle, the opposite was observed for the other paste. Nevertheless, both pastes had similar performances with respect to the polishing of the ceramic specimens. Further studies are required to assess the behavior of different polishing pastes because in the present study, only $R a$ was used as the roughness parameter.

Due to the increasing indication and fabrication of ceramic restorations on daily clinical practice and to the frequent need of performing finishing and polishing of ceramic surface to preserve its structural resistance and obtain a clinically acceptable smoothness, the findings of this work reinforce the need for association of suitable vehicles to diamond pastes for polishing procedures of ceramic restorations.

It may be concluded that: 1) Robinson bristle brush, felt wheel and buff disc were efficient vehicles to be used in association with a diamond polishing paste; 2) The use of rubber cup as a vehicle showed poor efficiency for mechanical polishing of the tested ceramic surfaces; 3) Both pastes provided similar and efficient polishing and may be recommended for use with an appropriated vehicle. 


\section{RESUMO}

Durante a confecção de restaurações de cerâmica aderidas, a adaptação cervical, o ajuste oclusal e o polimento/acabamento final são procedimentos a serem executados no consultório odontológico após a cimentação adesiva. Os ajustes finais podem resultar na perda do "glaze" da cerâmica, o que requer novo polimento da superfície da restauração, necessitando de atenção especial em relação aos materiais e instrumentos adequados. O objetivo deste estudo foi avaliar a eficiência de diferentes veículos associados a pastas diamantadas indicadas para polimento de cerâmicas odontológicas. Duas pastas de polimento diamantadas (Crystar Paste and Diamond Excell) associadas a quatro veículos (taça de borracha, escova de Robinson, roda de feltro e disco de feltro) foram avaliadas. A cerâmica Ceramco II foi selecionada para a confecção dos espécimes. A rugosidade superficial $(R a)$ dos espécimes de cerâmica foi determinada por um rugosímetro. Os dados foram submetidos a análise de variância a dois critérios e ao teste de Tukey com nível de significância de 5\%. Não houve diferença estatisticamente significante $(\mathrm{p}>0,01)$ entre as pastas de polimento avaliadas. Contudo, houve diferença significante $(p<0,01)$ entre os veículos. A interação veículo-pasta revelou diferença significante $(\mathrm{p}<0,05)$. Conlcuir que: 1$)$ A escova de Robinson, a roda de feltro e o disco de feltro foram veículos efetivos para serem usados em associação com as pastas de diamante; 2) O uso da taça de borracha como veículo foi menos eficiente para o polimento mecânico das superfícies cerâmicas; 3) Ambas as pastas de polimento apresentaram comportamento similar e eficiente e podem ser indicadas para o polimento final de restaurações cerâmicas com um veículo apropriado.

\section{REFERENCES}

1. Anusavice KJ. Recent developments in restorative dental ceramics. J Am Dent Assoc 1993;124:72-84.

2. McLean JW. Ceramics in clinical dentistry. Br Dent J 1988;164:187-194.

3. McLean JW. New dental ceramics and esthetics. J Esthet Dent 1995; 7:141-149.
4. Giordano RA, Pelletier L, Campbell S, Pober R. Flexural strength of an infused ceramic, glass ceramic, and feldspar porcelain. J Prosthet Dent 1995;73:411-418.

5. Segui RR, Sorensen JA. Relative flexural strength of six new ceramic materials. Int J Prosthodont 1995;8:239-246.

6. Quirynen M, Bollen CM. The influence of surface roughness and surface-free energy on supra and subgingival plaque formation in man: a review of the literature. J Clin Periodontol 1995;22:1-14.

7. Bollen CM, Lambrechts P, Quirynem M. Comparison of surface roughness of oral hard materials to the threshold surface roughness for bacterial plaque retention: a review of the literature. Dent Mat 1997;13:258-269.

8. Martinez-Gomis J, Bizar J, Anglada JM, Samso J, Peraire M. Comparative evaluation of four finishing systems on one ceramic surface. Int J Prosthodont 2003;16:74-77.

9. Chalifoux PR. Porcelain veneers. Current Opin Cosmet Dent 1994;1:58-66.

10. Jackson RD. Esthetic inlays and onlays. Current Opin Cosmet Dent 1994;1:30-39.

11. Anusavice KJ. Degradability of dental ceramics. Adv Dent Res 1992;6:82-89.

12. Sorensen JA. A rationale for comparison of plaque-retaining properties of crown systems. J Prosthet Dent 1989;62:264269.

13. Segui RR, Denry IL, Rosenstiel SF. Relative fracture toughness and hardness of new dental ceramics. J Prosthet Dent 1995;74:145-150.

14. Isidor Fbrondum K. A clinical evaluation of porcelain inlays. J Prosthet Dent 1995;74:140-144.

15. Molin M, Karlsson S. A clinical evaluation of the Optec inlay system. Acta Odontol Scand 1992;50:227-233.

16. Stenberg R, Matsson L. Clinical evaluation of glass ceramic inlays (Dicor). Acta Odontol Scand 1993;51:91-97.

17. Tidehag P, Gunne J. A 2-year clinical follow-up study of IPS Empress ceramic inlays. Int J Prosthodont 1995;8:456-460.

18. Riesgo O, Saulino D. Characterization of polished porcelains with diamond pastes. Rev Odonto Ciênc 1995;19:7-15.

Accepted July 5, 2006 